This is a post-peer-review, pre-copyedit version of an article published in Trends in Plant Science. The final authenticated version is available online

at: https://doi.org/10.1016/j.tplants.2020.10.012

\title{
The PEAPOD Pathway and Its Potential to Improve Crop Yield
}

Michele Schneider, ${ }^{1,2}$ Nathalie Gonzalez, ${ }^{3}$ Laurens Pauwels, ${ }^{1,2}$ Dirk Inzé, ${ }^{1,2,{ }^{*},+}$ and Alexandra Baekelandt ${ }^{1,2, *}$

${ }^{1}$ Ghent University, Department of Plant Biotechnology and Bioinformatics, 9052 Ghent, Belgium

2 VIB Center for Plant Systems Biology, 9052 Ghent, Belgium

${ }^{3}$ INRAE, Univ. Bordeaux, BFP, F33882 Villenave d'Ornon, France

${ }^{*}$ Equal contribution

† Correspondence: dirk.inze@psb.vib-ugent.be (D. Inzé)

ORCID IDs: 0000-0001-8833-0247 (M.S.), 0000-0002-3946-1758 (N.G.), 0000-0002-0221-9052 (L.P.), 0000-0002-3217-8407 (D.I.), 0000-0003-0816-7115 (A.B.)

KEYWORDS: organ growth, agronomic trait, crop engineering, leaf development, seed development, eudicot-specific

\section{Highlights}

- The TIFY proteins PPD1 and PPD2 recruit KIX8, KIX9 and NINJA to form repressor complexes which participate in the transcriptional machinery based on their binding partners.

- SAP-mediated proteasome-dependent degradation regulates PPD and KIX protein abundancies.

- $\quad$ The PPD/KIX/SAP module is widely conserved amongst higher plant species, excluding monocot grasses, and regulates leaf, flower, fruit and seed development in several crop species of agricultural importance.

- Emerging evidence suggests a broader role for the PPD pathway in controlling cell proliferation and developmental plasticity in a tissue-, developmental state- and/or environmental context-dependent manner. 


\begin{abstract}
A key strategy to increase plant productivity is to improve intrinsic organ growth. Some of the regulatory networks underlying organ growth and development, and interconnections between these networks are highly conserved. An example of such a growth-regulatory module with a highly conserved role in final organ size and shape determination in eudicot species is the PEAPOD (PPD)/KINASE-INDUCIBLE DOMAIN INTERACTING (KIX)/STERILE APETALA (SAP) module. Here, we review the proteins constituting the PPD pathway and their role in different plant developmental processes and explore options for future research. Moreover, we speculate on strategies to exploit the knowledge of the PPD pathway for targeted yield improvement to engineer crop traits of agronomical interest, such as leaf, fruit and seed size.
\end{abstract}

\title{
JAZ and PPD Proteins: So Similar, Yet So Different
}

Various regulators of organ size, shape and differentiation, their targets, interacting proteins and the interconnections amongst them have been described [1-6]. One such pathway with highly conserved functions for the development of distinct plant organs in various eudicot species is the PEAPOD (PPD) pathway. PPD1 and PPD2 are transcriptional regulators that, together with the JASMONATE ZIM-DOMAIN (JAZ) proteins and TIFY DOMAIN PROTEIN 8 (TIFY8), constitute the plant-specific class II TIFY protein family [7-11]. JAZ proteins contain a ZINC-FINGER PROTEIN EXPRESSED IN INFLORESCENCE MERISTEM (ZIM) domain, containing a core TIF[F/Y]XG motif and a jasmonic acid (JA)-associated (Jas) domain, and are well-described as negative regulators of JA signalling (Figure 1A) $[9,12,13]$. In the absence of $J A$, they bind and repress multiple transcriptional regulators, including MYC and R2R3 MYB transcription factors (Figure 1A) $[9,14-$ 19]. To function as transcriptional repressors, JAZ proteins act as adaptors to recruit the corepressor TOPLESS (TPL) [9,20-22], which is, together with TOPLESS-RELATED (TPR) proteins, involved in several processes, such as meristem maintenance, hormone signalling and the control of flowering time [22-24]. Whereas JAZ5 to JAZ8 in Arabidopsis thaliana (arabidopsis) contain an ETHYLENE RESPONSE FACTOR (ERF)-ASSOCIATED AMPHIPHILIC REPRESSION (EAR) motif and can directly interact with TPL, the remaining JAZ proteins lack an EAR domain and interact via their ZIM domain with NOVEL INTERACTOR OF JAZ (NINJA), an EAR motif-containing adaptor protein 
that recruits TPL to the JAZ repressor complex (Figure $1 A)[18,21,22,25-30]$. During specific JA responses, additional adaptor proteins can be recruited, such as the EAR MOTIF-CONTAINING ADAPTOR PROTEIN (ECAP) which negatively regulates JA-induced anthocyanin accumulation by connecting TPR2 to some JAZ proteins [31]. Upon treatment with 7-iso-(+)-jasmonoyl-L-isoleucine (JA-Ile), the bioactive form of JA [32], JAZ proteins interact with CORONATINE INSENSITIVE 1 (COI1), an F-box protein that is part of the SKP1/CULLIN1/F-BOX PROTEIN (SCF) E3 ubiquitin ligase complex (Figure 1A) [33-36]. The interaction results in the $\mathrm{SCF}^{\mathrm{CO} 11}$-mediated ubiquitination and 26S-mediated proteasomal degradation of JAZ proteins, release of the JAZ-bound transcriptional regulators and induction of the JA response $[9,12,33,34,36]$. The interaction between JAZ proteins and a number of JA signalling regulators, such as MYCs, R2R3 MYBs and COI1, is mediated via the C-terminal Jas domain (Figure 1A) $[9,15,16,18,33,37-39]$.

Similar to JAZ proteins, PPD proteins contain a central ZIM domain and a C-terminal Jas domain, though slightly modified (Jas*), mediating homo- and heterodimerisation with PPD, JAZ and NINJA proteins $[10,11,40,41]$ and with transcriptional regulators (Figure 1B), such as the basic HELIXLOOP-HELIX (bHLH) transcription factors MYC3/MYC4 and the chromatin remodelling complex member LIKE HETEROCHROMATIN PROTEIN 1 (LHP1) [42,43]. Interestingly, binding affinities for MYC3 are predicted to be lower with PPD proteins compared with JAZ proteins, likely to be caused by a single amino acid substitution within the Jas domain [44]. This finding further confirms the close phylogenetic relationship between JAZ and PPD proteins, though also demonstrates that PPD and JAZ proteins might present mild differences in terms of interaction behavior [44]. In agreement, PPD proteins contain an additional N-terminal PPD domain that is indispensable for the interaction with KINASE-INDUCIBLE DOMAIN INTERACTING 8 (KIX8) and KIX9, also functioning as TPL-adaptor proteins (Figure 1B) [45]. Whereas JAZ protein stability is regulated by the F-box protein COI1 $[33,34,36]$, the PPD/KIX-complex is poly-ubiquitinated by the F-box protein STERILE APETALA (SAP) containing SCF-complex (SCF ${ }^{\text {SAP)}}$, resulting in its proteasome-dependent degradation (Figure 1B) $[46,47]$. Whether SAP-mediated degradation of the PPD/KIX repressor complex results in the activation of downstream genes due to an abolished repression or the release of transcription factors, allowing their participation in the transcriptional machinery, influencing the expression of downstream genes indirectly, is currently largely unknown. 
Moreover, it remains elusive how SAP activity is regulated and what triggers SAP-mediated degradation, which can be a developmental cue, a hormonal cue and/or based on environmental stimuli (Figure 1B).

In conclusion, PPD and JAZ proteins demonstrate high similarities in terms of protein structure, the molecular mechanisms in which they are involved and how their activity is regulated. Nonetheless, the exact protein partners and the biological processes in which PPD and JAZ proteins are involved, appear to be slightly distinct.

\section{The PPD Pathway Has a Conserved Role in Eudicot Developmental Processes}

\section{Leaf Development}

In arabidopsis, PPD1/2 and KIX8/9 limit asymmetric divisions of meristemoids, triangular stemcell like cells that can divide reiteratively before differentiating into stomata $[45,48-52]$. Upon down-regulation of $P P D$ or $K I X$ or up-regulation of $S A P$, arabidopsis plants display propeller-like rosettes with enlarged dome-shaped leaves and an increase in meristemoid asymmetric cell divisions (Figure 2A) [45-47]. In addition to limiting meristemoid proliferation in leaves [45], referred to as the secondary cell cycle arrest, PPD proteins also control the shape of the primary cell cycle arrest front, denoting the arrest of pavement cell divisions [40]. In ppd and ninja mutants, the primary cell cycle arrest front is convex-shaped compared with a relatively straight front in wild-type leaves, leading to increased cell divisions in the central compared with the marginal leaf blade regions [40,53]. In concordance, ppd, ninja, kix8-kix9 and 35S::SAP mutants show an increased expression of the direct PPD2 target genes CYCD3;2 and CYCD3;3 [40,45-47]. Plants mutated in NINJA or constitutively overexpressing CYCD3;2 also produce propeller-like rosettes with dome-shaped leaves, but lack the increase in the number of meristemoid amplifying divisions and in the leaf area $[40,45,51]$. These data demonstrate that the ppd leaf shape phenotype results, at least partially, from an increased CYCD3 activity, and that the PPD pathway is also involved in primary cell division [40]. Interestingly, SAP was previously identified SUPPRESSOR OF DA1 (SOD3) [46], with DA1 also being a regulator of organ size by limiting cell division [54]. Surprisingly, combining the mutant alleles da1-1 or enhancer of da1-1-2 (eod1-2) with an artificial miRNA line downregulating PPD1 and PPD2 (ami-ppd) results in plants bigger compared with the wild type, though smaller than the expected size for additive, hence 
independent, effects [55]. This finding may indicate an interaction between the PPD and DA1 pathway, though no direct molecular link was established so far [55]. Moreover, not only the epidermal cell number, but also the palisade cell number is increased in ppd arabidopsis mutants compared with the wild type [42]. Previous findings demonstrate that epidermal and mesophyll cell proliferation are tightly coordinated, involving molecular mechanisms such as retrograde signalling [56] and the cell-to-cell movement of the transcriptional regulator Arabidopsis thaliana GRF-INTERACTING FACTOR 1 (AtGIF1)/ANGUSTIFOLIA3 (AN3) [57]. Similarly, also the arrest of meristemoid proliferation might be interlinked with the arrest of mesophyll and pavement cell division $[51,56]$, though currently still largely unknown. In agreement with the leaf phenotypes observed in PPD signalling mutants, PPD1 and PPD2 are expressed throughout all leaf tissues [43]. In the epidermis, PPD2 appears to be specifically expressed in stomatal guard cells [43], corresponding with the role of PPD2 in limiting meristemoid asymmetric cell division [45,51], putatively by signalling the transition from asymmetric to symmetric divisions. PPD genes are also proposed to be expressed at the shoot apical meristem (SAM), from which leaf primordia originate [43]. As increases in meristem size may contribute to an increase in final leaf area $[1,58,59]$, PPD proteins might also be involved in controlling meristem size, through an unknown mechanism. Although these findings suggest that PPD proteins may act in a cell-autonomous manner, additional in-depth analysis will be required to study the expression patterns of the members of the PPD pathway at a higher spatiotemporal resolution to further elucidate their mode of action.

Production of enlarged leaves with uneven lamina is also observed upon down-regulation of $P P D$ or KIX and up-regulation of SAP orthologues in Medicago truncatula (medicago; BIG SEEDS 1, mtbs1-1, SMALL LEAF AND BUSHY 1 (SLB1)) [60,61], Vigna mungo (black gram; MULTIPLE ORGAN GIGANTISM (MOG), VIMPPD) [62], Pisum sativum (pea; ELEPHANT-EAR-LIKE LEAF 1 (ELE1), PsPPD, BIGGER ORGANS (BIO), PsKIX) [63], Glycine max (soybean; BIG SEEDS 1/2 (BS1/2), GmPPD1/2, GmKIX8-1) [60,62,64,65], Capsella rubella (CrSAP) [66], Cucumis sativus L. (cucumber; LITTLELEAF (LL), CSSAP) [67] and Populus tremula $\times$ P. alba (P. $x$ canescens, grey poplar; BIG LEAF (BL), SAP orthologue) [68], suggesting a highly conserved role for the PPD pathway in leaf growth regulation across rosid eudicot species (Table 1, Figure 3). More recently, also Solanum lycopersicum 
(tomato) SIkix8-kix9 plants were shown to produce enlarged and rippled leaves, demonstrating that the pathway is also conserved in asterid eudicots (Table 1, Figure 3) [69].

Transcription factors recruited to the PPD/KIX/NINJA complex during leaf development have not yet been described. Nonetheless, the expression of GIF1/AN3 was significantly increased in young leaves of medicago (MtGIF1/2) and soybean (GmGIF1) upon down-regulation of PPD [60]. AtGIF1/AN3 acts together with AtGIF2 and AtGIF3 as a transcriptional co-activator that interacts with GROWTH-REGULATING FACTOR (GRF) proteins to control plant organ growth by positively regulating cell proliferation [42,70-75]. Since GRF5 and AtGIF1/AN3 promote primary cell division during leaf development $[71,76,77]$, PPD proteins may also limit primary cell division in leaves by repressing the expression of AtGIF1/AN3, similar as during arabidopsis seed development (see 'Flower, Fruit and Seed Development') [42].

Findings from pea, Lotus japonicus (lotus), medicago and arabidopsis suggest that WUSCHELRELATED HOMEOBOX (WOX) proteins may also be involved in PPD-mediated leaf development (Table 1) $[63,78]$. Besides with PPD orthologues (ELEPHANT EAR-LIKE LEAF 1, ELE1), KIX orthologues (BIGGER ORGANS, BIO) also interact with the WOX1 orthologue group in lotus (NARROW ORGANS 1, LjNAO1) and in pea (PsLATHYROIDES, PsLATH) [63]. Moreover, expression of PSGRF5 in pea is dependent on both PsLATH and the PsBIO/PsELE1 module, and there are genetic interactions identified between WOX1, WOX3 and AtGIF1/AN3 in arabidopsis, and between the PsBIO/PsELE1 module and PsLATH to control organ development in pea $[63,78]$. Furthermore, ASYMMETRIC LEAVES 1 (AS1) was identified as direct target gene of PPD2 [45] and plants constitutively expressing AS1 also show propeller-like rosettes and dome-shaped leaves [79]. AS1 represses distinct KNOTTED1-LIKE HOMEOBOX (KNOX) genes and is involved in the regulation of adaxial/abaxial leaf patterning [80-82], suggesting that also adaxial/abaxial leaf polarity might be affected in $P P D / K I X / N I N J A / S A P$ mutants. Altogether, these findings demonstrate a role for the PPD/KIX/NINJA/SAP module in controlling leaf size and shape determination by limiting cell division via a panoply of molecular mechanisms, some being still largely elusive (Figure 3 ).

\section{Flower, Fruit and Seed Development}


In multiple eudicot species, down-regulation of $P P D$ or KIX or up-regulation of SAP orthologues also significantly affects other plant organs (Table 1, Figure 3 ) $[42,46,47,51,60,62,64,65,68,83]$. Arabidopsis $\triangle p p d$ mutants, in which both $P P D$ loci are deleted, produce shorter and wider seed pods ('pea pod-like') with undulated silique walls (Figure 3) [51]. In agreement, PPD1 and PPD2 are highly expressed throughout early arabidopsis seed pod development $[43,51,84]$. Moreover, strong GmPPD soybean mutants display twisted pods [64] and Slkix8-kix9 tomato plants produce enlarged fruits with an increased pericarp thickness (Figure 3) [69]. Also ele1 and bio pea mutants display enlarged flowers [63], whereas down-regulation of the SAP orthologue in Capsella rubella causes the production of smaller petals due to a decrease in petal cell numbers [66]. In line with these observations, overexpression of the SAP orthologue in cucumber results in the production of bigger organs, including fruits, leaves and flowers (Figure 3) [67], and also in medicago, the SAP orthologue SLB1 regulates organ size by targeting the PPD soybean orthologue BS1 for degradation (Figure 3) [61].

Besides fruit size, disruption or overexpression of $P P D 1 / 2, K I X 8 / 9$ or $S A P$ also affects seed size and weight in arabidopsis $[42,46,47,83]$, as well as in medicago (BS1, mtbs1-1, SLB1) [60,61], black gram (MOG, VmPPD) [62], pea (ELE1, PsPPD; BIO, PsKIX) [63], soybean (BS1, GmPPD1/2; GmKIX81/-2) $[60,62,64,65]$ and cucumber (LL, CSSAP) [67] (Table 1, Figure 3). Whereas also soybean seed quality, more specifically the amino acid content, is significantly improved in bs1 seeds compared with the wild type [60], the increase in seed size comes at the expense of seed number in black gram [62] and soybean $[62,64]$. Recently, it was shown that the increase in soybean seed and leaf size of gmkix8-1 mutants can be uncoupled from each other [65]. Comparisons between heteroand homozygous gmkix8-1 plants revealed that whereas homozygous mutants produce enlarged leaves, heterozygous plants produce wild type-like leaves [65]. In contrast, both hetero- and homozygous gmkix8-1 plants produce enlarged seeds, suggesting GmKIX8-1 haploinsufficiency during seed, but not during leaf development [65]. These findings indicate that the increase in seed size observed in gmkix8-1 plants does not result indirectly from an increased energy production due to the larger leaves, but that the PPD module restricts seed size in a direct manner [65]. During arabidopsis seed development, the PPD/KIX complex interacts with the bHLH transcription factors MYC3/MYC4 to directly bind and repress the expression of AtGIF1/AN3 
(Figure 2) [42]. In agreement, the expression patterns of KIX8, KIX9, PPD1, PPD2, MYC3, MYC4 and AtGIF1/AN3 are partially overlapping during arabidopsis ovule and seed development [42], and seeds of atgif1/an3 arabidopsis plants are significantly smaller compared with the wild type due to a decrease in cell numbers $[42,74]$. In contrast, however, enlarged embryos and increased embryonic, seed and cotyledon cell sizes were described for the an3-4 allele $[85,86]$. These findings may indicate that mutant allele-specific effects could underlie the different reported effects of AtGIF1/AN3 on seed size, though requiring further investigation. In addition, it is currently unknown whether cell-to-cell mobility of AtGIF1/AN3, as reported for leaves [57], may also impact seed development. Upon down-regulation of the PPD orthologues, the expression of GIF1/AN3 is also significantly increased in seeds of medicago (MtGIF1) and soybean (GmGIF1) [60]. Altogether, these findings demonstrate the involvement of the PPD/KIX/SAP module in controlling the growth and development of reproductive organs and seeds, putatively through similar conserved mechanisms [42,47,60,61,67]. Nonetheless, the atgif1/an3 mutation complements the increase in seed size of arabidopsis ppd, kix8-kix9 and 35S::SAP plants only partially [42], suggesting the presence of additional molecular mechanisms underlying the seed size alterations in PPD signalling mutants (Figure 2) [83]. Among others, brassinosteroids (BRs) are required for normal seed size, shape and weight establishment [87] and plants overexpressing the BR-biosynthesis gene DWARF 4 (DWF4ox) [88,89] or BRASSINOSTEROID INSENSITIVE 1 (BRI1, $B R / 10 x$ ), encoding the BR receptor [90], display an increased seed weight [83]. Interestingly, arabidopsis BRI1ox-GFP plants also produce rosettes with enlarged dome-shaped leaves, reminiscent of ppd, kix8-kix9 and 35S::SAP mutants [90-92]. Since PPD proteins were previously proposed to restrict BR biosynthesis and signalling [83], the increased size of arabidopsis ppd, kix8-kix9, myc3/4 and 35S::SAP seeds [42] could also result from increased BR signalling (Figure 2), though elusive so far.

\section{Vascular Development}

The plant's vascular network consists of phloem and xylem and is in arabidopsis leaves predominantly generated by the activity of (pro)cambium cells recruited from the mesophyll tissue layer [51,93-97]. Like meristemoids, (pro)cambium cells are referred to as dispersed meristematic cells and might thus be regulated in a similar manner [51]. Preliminary experimental 
data suggest a potential role for the PPD pathway in regulating vascular development (Figure 2) $[51,68] . \Delta p p d$ plants exhibit a more complex venation pattern and increased procambium cell numbers in cotyledons $[51,83]$. In addition, xylem vessel numbers are increased compared with the wild type, whereas cotyledons of PPD-OE plants display reduced vascular growth $[51,83]$. In concordance, $P P D$ expression is high in tissues that may correspond with the cotyledon and leaf vascular system $[43,51]$ and overexpression of the SAP orthologue $B L$ in grey poplar results in disturbed xylem development and reduced stem diameters [68], further supporting a putative involvement of the PPD pathway in vascular development. During vascular development, the TARGET GENE OF MONOPTEROS 5 (TMO5)-LONESOME HIGHWAY (LHW) complex directly induces the expression of the cytokinin biosynthesis genes LONELY GUY 3 (LOG3) and LOG4, resulting in an increased (pro)cambium cell proliferation (Figure 2) [94,98-100]. TMO5-LHW activity can, however, be reduced by SUPPRESSOR OF ACAULIS-LIKE (SACL) transcription factors, as these can compete with TMO5 for binding with LHW [101,102]. SACL expression is strongly induced by the polyamine thermospermine, produced by ACAULIS 5 (ACL5) $[103,104]$. Interestingly, $A C L 5$ expression is reduced in $\triangle p p d$ arabidopsis plants [83] and PPD2 can directly bind to the promoter of $A C L 5$ in arabidopsis cell cultures $[45,83]$, suggesting that PPD proteins may limit TMO5-LHW activity [83]. These findings suggest that the PPD/KIX/SAP module may limit meristemoid and (pro)cambial cell proliferation in eudicots to regulate the spacing of stomata and the vascular system, respectively, though subject for future research.

\section{Flowering Time}

Besides the effects on organ growth, arabidopsis ppd and arabidopsis and tomato kix8-kix9 mutants display delayed flowering (Table 1) $[69,83]$. To induce the transition from vegetative to reproductive growth, the transcription factor CONSTANS (CO) is stabilised and activates the expression of FLOWERING LOCUS $T(F T)$ in the leaf phloem companion cells [105]. FT is subsequently transported to the SAM to initiate flower formation [105]. In arabidopsis, CO activity is, amongst others, counteracted by SCHLAFMUTZE (SMZ), which represses multiple flowering time regulatory genes, including FT (Figure 2) [106]. In concordance with the delayed flowering phenotype of $p p d$ and kix8-kix9 plants, $S M Z$ expression is increased in arabidopsis amippd and kix8-kix9 leaves [45,83]. Similarly, the expression of APETALA2d (AP2d), a SMZ 
orthologue, is up-regulated in tomato Slkix8-kix9 compared with wild-type leaves [69]. Besides $S M Z$, also several other genes encoding proteins affecting CO activity are differentially expressed in arabidopsis ppd compared with wild-type plants [45,83], including NUCLEAR FACTOR $Y$ SUBUNIT B2 (NF-YB2) [107], TARGET OF EARLY ACTIVATED TAGGED 2 (TOE2) [108,109] and SUPPRESSOR OF PHYA-105 1 (SPA1) [106,110,111], and the promoters of SMZ, NF-YB2 and TOE2 are directly bound by PPD2 in arabidopsis cell cultures (Figure 2) [45]. Taken together, these findings suggest a role for the PPD pathway in flowering time determination, though the exact underlying molecular networks are still largely elusive.

\section{Hormone and Light Signalling}

Amongst the genomic regions bound by PPD2, 'hormone metabolism' is an overrepresented PageMan category $[45,112]$ and 'hormone biosynthesis process', 'regulation of hormone levels' and 'response to light stimulus' are amongst the significantly overrepresented gene ontology (GO) terms of genes differentially expressed in arabidopsis ppd seedlings [83,112]. These findings suggest a potential role for the PPD pathway in hormone and light signalling processes.

PPD proteins likely diverged from JAZ proteins, negative regulators of JA signalling [7-10], and both PPD and most JAZ proteins interact with the adaptor protein NINJA, also involved in JA signalling (Figure 1) $[20,25,26,40,45]$. Moreover, DWARF IN LIGHT 1 (DFL1) is up-regulated in arabidopsis ami-ppd and arabidopsis and tomato kix8-kix9 leaves and the promoter of DFL1 is bound by PPD2 in arabidopsis cell cultures $[45,69]$. Amongst the nineteen GRETCHEN HAGEN 3 (GH3) proteins, described to be involved in maintaining auxin homeostasis by conjugating amino acids to excess auxin [113-115], GH3.3, GH3.5 and GH3.6 (DFL1) additionally conjugate amino acids to JA (Figure 2) $[116,117]$. Interestingly, also the expression of $G H 3.3$ is increased in arabidopsis ami-ppd compared with wild-type leaves [45]. Although these observations suggest a potential involvement of PPD proteins in JA signalling, PPD expression and PPD protein stability are not affected by JA treatment [20] and the phenotypes of $p p d$ mutants are likely unrelated to JA signalling $[40,45,51,83]$. Whereas a direct involvement in JA signalling is unlikely, PPD proteins are proposed to be involved in several other hormonal pathways. It has been suggested that PPD proteins restrict BR biosynthesis and signalling (see 'Flower, Fruit and Seed Development') and 
arabidopsis ppd mutants show a differential response compared with wild-type plants for several other plant hormones, though mostly based on preliminary data [83].

Arabidopsis ppd plants also share phenotypes with shade-grown plants, including abscisic acidinsensitive seed germination, and hypocotyl and petiole elongation $[51,83,118,119]$. Moreover, PPD proteins are proposed to directly repress SPA1 and activate ATTENUATED FAR-RED RESPONSE (AFR) [83], a negative and positive regulator of light signalling, respectively $[111,120]$ and overexpression of PHYTOCHROME $B$ (phyBOE) is epistatic to $\triangle p p d$ with regard to the hypocotyl length and the flowering time phenotypes [83]. Although these observations suggest a putative interaction between the PPD pathway and hormone and light signalling (Figure 2), additional research will be required to validate an interplay between the different signalling pathways and to identify the steering molecular players.

\section{PPD1/PPD2 and KIX8/KIX9 Control Organ Growth in a Partially Redundant Manner}

In arabidopsis, genomic transgenes of PPD1 or PPD2 can rescue the $\triangle p p d$ [51] and ami-ppd [43] mutant leaf size and shape phenotypes. In addition, overexpression of PPD1 or PPD2 results in the production of small seeds, whereas seed area, seed weight and leaf area are significantly increased in $p p d 1$ ppd2-cr and $p p d 1$-cr ppd2 double mutants compared with the respective single mutants (Table 1) [42,83]. In agreement, PPD1 and PPD2 are expressed in an overlapping manner in arabidopsis, including young leaf primordia and during the early seed pod and seed developmental stages [42,43,51]. Similarly, overexpression of KIX8 or KIX9 results in the formation of small seeds compared with the wild type [42], and leaf and seed phenotypes (Table 1) and the increases in expression of the PPD2 target genes are most pronounced in kix8kix9 double mutants compared with the respective single mutants $[42,45,69]$. Although these findings indicate that PPD and KIX proteins control leaf, fruit and seed development in a redundant manner, PPD1, PPD2, KIX8 and KIX9 also appear to have specificities. Whereas ppd2 mutants, for instance, display propeller-like rosettes with enlarged dome-shaped leaves and produce seeds with an increased area and weight, ppd1 rosettes and seeds are indiscernible from those of wild type plants $[42,43,46]$. Analogously, kix 8 arabidopsis mutants exhibit mild propellerlike rosettes with dome-shaped leaves, enlarged seeds and a slight increase in expression of the PPD2 target genes compared with the wild type, whereas kix9 plants are indistinguishable from 
wild-type plants, both at a phenotypical and molecular level $[42,45]$. In concordance, whereas the Slkix9 tomato mutant produces wild type-like leaves, the leaf phenotype of Slkix8 mutants is intermediate of that of Slkix8-kix9 and wild-type plants [69]. Altogether, these findings imply that although PPD and KIX proteins are functionally redundant, PPD2 and KIX8 appear to act as predominant players during leaf and seed development, likely to result from subtle differences in expression level and/or pattern [69]. In the future, it will be interesting to further investigate and compare the spatio-temporal expression of $P P D 1 / 2$ and $K I X 8 / 9$ to better understand tissuespecific interactions and their individual contribution to plant organ growth. The previous identification of KIX8-specific putative interaction partners [45] may even suggest PPDindependent functions for KIX proteins, though unexplored so far.

\section{Why Are PPD/KIX/SAP Orthologues Absent in Poaceae?}

Though being absent in non-photosynthetic eukaryotes and green algae, several TIFY protein family members have orthologues in monocot and eudicot species [7,8,41,121-127]. Interestingly, however, whereas highly conserved in both sequence and function across rosid and asterid species constituting most of the core eudicots $[46,47,60-62,64,69]$, PPD/KIX/SAP orthologues appear to be absent in Poaceae (grasses) $[43,45,46]$. The phylogenetic distribution of PPD/KIX/SAP orthologues points towards a conserved function for the PPD/KIX/SAP module in processes that are intrinsically different between eudicots and monocot grasses $[2,45,46]$. In agreement, although cellular and molecular mechanisms governing leaf growth in eudicots and grasses are largely conserved $[2,29,128,129]$, certain specificities remain. Whereas stomata in eudicots are distributed in a random manner, following the 'one-cell spacing rule', monocot grasses show a linear stomatal organisation and lack stomatal precursor meristemoid cells $[2,29,128-131]$. Moreover, the venation pattern is reticulate in eudicot leaves, and parallel-like in monocot grasses [130]. Findings from lotus and pea indicate that the PPD/KIX module might interact, directly or genetically, with LjNAO1 and PsLATH, orthologues of AtWOX1 and MtSTENOFOLIA (STF) [63,132]. Overexpression of MtSTF in Panicum virgatum (switch grass), Oryza sativa (rice) or Brachypodium distachyon (Brachypodium) results in wider leaf laminae, in an increased leaf vein number and stem diameter, and, upon strong overexpression, in leaf blade twisting and curling [133]. Also in Triticum aestivum (wheat), overexpression of MtSTF results in 
wider leaves, more leaf veins and increased epidermal cell divisions [134]. WOX1 and its orthologues are described as regulators of leaf blade outgrowth and vascular development $[135,136]$ and, unlike other WOX genes, lack orthologues in monocot grasses $[136,137]$, in which WOX3 proteins predominantly regulate lateral organ development [138-141]. Several main players during vascular development, however, such as TMO5, LHW, ACL5, LOG and SACL (see 'Vascular Development'), have orthologues in grasses, such as in rice and Sorghum bicolor (sorghum) [142]. These findings indicate that the PPD pathway is not required to modulate (pro)cambial cell proliferation in grasses, but that other proteins might be present to perform a similar function. Accordingly, combined with the lack of meristemoids, the PPD/KIX/SAP module might have become obsolete for leaf growth in grasses. Interestingly, however, PPD, KIX and SAP orthologues are present in several non-grass monocot species, such as Musa acuminata (banana) and Elaeis guineensis (oil palm) [43], as well as in the basal angiosperm Amborella trichopoda and even lycophytes [43], though it is currently unknown whether their function is conserved. In the future, it might be useful to perform more in-depth phylogenetic analyses to shed light on the conservation, functionality and evolutionary history of the PPD/KIX/SAP module.

\section{Targeting the PPD Pathway to Improve Specific Plant Agronomic Traits}

The significant increases in shoot, fruit and seed biomass in multiple eudicots upon downregulation of $P P D$ or $K I X[42,45,51,60,62-64,69]$ or up-regulation of SAP genes $[46,47,61,67,68]$ imply that the PPD pathway may hold great potential from a biotechnological point of view (Table 1, Figure 3). Increased fruit size, for instance, as observed in Slkix8-kix9 tomato [69], ele1 and bio pea [63] or SAP-overexpressing cucumber lines [67], was amongst the main selection criteria for nearly all fruit crops during domestication and still is today $[143,144]$. Moreover, the I/ cucumber mutant, producing smaller organs proposed to result from an abolished interaction with and degradation of the KIX orthologues, was sold as a pickling cucumber variety and thus also considered interesting from an agronomic point of view [67]. Hence, the knowledge of the PPD pathway may be exploited to direct plant breeding or to enhance the success rate to generate crops with increased agronomical traits. Alterations in the size and/or shape of flowers and/or leaves might for instance be of interest to breed new varieties of ornamental plants. Besides organ size and shape, the PPD pathway also controls several other traits with major potential to 
be explored in biotechnological engineering approaches. The increased amino acid content in soybean seeds upon down-regulation of GMPPD [60], for instance, suggests to exploit the PPD pathway to breed for crop varieties with an improved seed nutritional value. Moreover, overexpression of the SAP orthologue $B L$ results in an impaired xylem formation and overall reduced stem diameter, pointing towards the potential or targeting the PPD/KIX/SAP module to improve wood development [68].

Targeting genes that act in multiple plant organs or at distinct developmental stages, as demonstrated for the PPD pathway, may however result in undesirable pleiotropic effects (Table 1) [145]. The delayed flowering time of arabidopsis ppd and kix8-kix9 [83] and tomato Slkix8-kix9 [69] plants and the fact that the increased seed sizes in black gram [62] and soybean $[62,64]$ were, especially for strong alleles, at the expense of seed number, may for instance be unprosperous for farming purposes. Interestingly, many of the alleles selected during domestication are not severe gain- or loss-of-function alleles of genes involved in crop development, but result from mutations in cis-regulatory elements (CREs) [145-147]. Sequence variation in CREs can modify a specific aspect of the gene expression profile, leading to mild changes in gene expression level and/or pattern, including the developmental timing and tissue specificity $[145,148]$. Specific agronomic traits, such as fruit or seed size or seed quality, could for instance be improved by engineering specific CREs involved in the transcriptional regulation of PPD signalling members to modify a specific aspect of their expression profile $[145,149-151]$. Analogously, it was recently shown that soybean plants heterozygous for small deletions in the GmKIX8-1 promoter produce enlarged seeds while maintaining wild-type leaf size [65], suggesting that this regulatory element might have great potential to increase seed size using a CRE-targeting approach. This hypothesis is further strengthened by the fact that the described mutation in the GmKIX8-1 promoter is associated with the 'big seed' quantitative trait locus qSw17-1 in multiple soybean populations [65]. Combining the knowledge of CREs involved in transcriptional regulation with the identification of upstream regulators or downstream target genes involved in specific PPD-regulated processes, could be another asset in fine-tuning biotechnological approaches. During arabidopsis seed development, for example, the PPD/KIX/MYC complex directly binds to a G-box sequence in the promoter of AtGIF1/AN3, encoding a positive regulator 
of seed size and weight, and represses its expression (Figure 2) [42,72,152,153]. Besides the members constituting the PPD pathway and their functionality, also their transcriptional regulation may be conserved in a broad range of eudicot species. Accordingly, targeting specific CREs bound by the PPD/KIX complex during seed development could be a promising strategy to improve for instance seed size and quality in distinct crops of agricultural importance. Though of substantial applied interest and offering major potential to improve specific agronomic traits, CREs and their role in organ- or developmental-specific processes are currently still largely elusive for members constituting the PPD pathway.

\section{Concluding Remarks and Future Perspectives}

An increasing number of studies highlight a conserved role for the PPD pathway in regulating organ growth in various eudicot species, predominantly by restricting cell proliferation, and reveal interconnections with other growth-regulatory modules, though often preliminary and missing strong evidence. Nonetheless, these findings indicate that targeting the PPD pathway may hold great potential for targeted yield improvement of crops with a high agricultural and economical value. The considerable increase in knowledge of the members of the PPD pathway and their role during organ growth indicates that this pathway may act as a master switch controlling more aspects of plant growth and development than initially anticipated, leaving still much to be explored in the future (see 'Outstanding Questions Box'). The complex phenotypes of PPD signalling mutants and the diversity in target genes may result from the fact that the intrinsic role of PPD/KIX proteins is to limit developmental plasticity, crucial to avoid excessive growth responses. As such, the PPD/KIX/NINJA complex might act as a general adaptor complex, interacting with various transcriptional regulators (i) to recruit the TPL machinery to specific DNA regions or (ii) to shield transcription factors from interactions with other proteins in a tissue-, developmental state- and/or environmental context-dependent manner. Whereas impressive biomass increases are obtained by modifying PPD signalling in various eudicot species, this is often accompanied with undesirable effects. In the future, a targeted engineering of the PPD pathway, for instance by targeting specific downstream target genes or specific CREs using modern genome-editing techniques, could harbour great potential to improve specific plant agronomic traits and generate higher-yielding crop varieties. Accordingly, it will be interesting, 
from both a scientific and a more applied perspective, to further untangle the members constituting the PPD pathway, their transcriptional regulation and their involvement in distinct processes. This may render a better view on the variety of processes controlled by the PPD pathway and will allow to further unravel the interconnections amongst distinct growthregulatory modules.

\section{Acknowledgements}

The authors would like to thank Annick Bleys for proofreading and submitting the manuscript. This work was supported by Ghent University (BOF-Methusalem projects BOFMET2015000201 \& B/09140/02) and by the Research Foundation Flanders (FWO research project 3G038719).

\section{Author contributions}

$M S$ and $A B$ wrote the manuscript. NG, $L P$ and DI complemented the writing. $A B$ and $D I$ supervised the writing.

\section{References}

1. Gonzalez, N. et al. (2012) Leaf size control: complex coordination of cell division and expansion. Trends Plant Sci. 17, 332-340

2. Nelissen, H. et al. (2016) Leaf growth in dicots and monocots: so different yet so alike. Curr. Opin. Plant Biol. 33, 72-76

3. Hepworth, J. and Lenhard, M. (2014) Regulation of plant lateral-organ growth by modulating cell number and size. Curr. Opin. Plant Biol. 17, 36-42

4. Beemster, G.T.S. et al. (2005) Genome-wide analysis of gene expression profiles associated with cell cycle transitions in growing organs of Arabidopsis. Plant Physiol. 138, 734-743

5. Tsukaya, H. (2013) Leaf development. The Arabidopsis book 11, e0163

6. Vercruysse, J. et al. (2020) Molecular networks regulating the cell division during leaf growth in Arabidopsis. J. Exp. Bot. DOI: 10.1093/jxb/erz522

7. Bai, Y. et al. (2011) Origin and evolutionary analysis of the plant-specific TIFY transcription factor family. Genomics 98, 128-136

8. Vanholme, B. et al. (2007) The tify family previously known as ZIM. Trends Plant Sci. 12, 239244

9. Pauwels, L. and Goossens, A. (2011) The JAZ proteins: a crucial interface in the jasmonate signaling cascade. Plant Cell 23, 3089-3100

10. Cuéllar Pérez, A. et al. (2014) The non-JAZ TIFY protein TIFY8 from Arabidopsis thaliana is a transcriptional repressor. PLOS ONE 9, e84891

11. Zhang, Y. et al. (2012) Genome-wide identification and analysis of the TIFY gene family in grape. PLOS ONE 7, e44465 
12. Kazan, K. and Manners, J.M. (2012) JAZ repressors and the orchestration of phytohormone crosstalk. Trends Plant Sci. 17, 22-31

13. Chini, A. et al. (2016) Redundancy and specificity in jasmonate signalling. Curr. Opin. Plant Biol. 33, 147-156

14. Cheng, Z. et al. (2011) The bHLH transcription factor MYC3 interacts with the jasmonate ZIM-domain proteins to mediate jasmonate response in Arabidopsis. Mol. Plant 4, 279-288

15. Fernández-Calvo, P. et al. (2011) The Arabidopsis bHLH transcription factors MYC3 and MYC4 are targets of JAZ repressors and act additively with MYC2 in the activation of jasmonate responses. Plant Cell 23, 701-715

16. Niu, Y. et al. (2011) Characterization of JAZ-interacting bHLH transcription factors that regulate jasmonate responses in Arabidopsis. J. Exp. Bot. 62, 2143-2154

17. Song, S. et al. (2011) The jasmonate-ZIM domain proteins interact with the R2R3-MYB transcription factors MYB21 and MYB24 to affect jasmonate-regulated stamen development in Arabidopsis. Plant Cell 23, 1000-1013

18. Qi, T. et al. (2011) The Jasmonate-ZIM-domain proteins interact with the WDRepeat/bHLH/MYB complexes to regulate jasmonate-mediated anthocyanin accumulation and trichome initiation in Arabidopsis thaliana. Plant Cell 23, 1795-1814

19. Qi, T. et al. (2015) Regulation of jasmonate-mediated stamen development and seed production by a bHLH-MYB complex in Arabidopsis. Plant Cell 27, 1620-1633

20. Pauwels, L. et al. (2010) NINJA connects the co-repressor TOPLESS to jasmonate signalling. Nature 464, 788-791

21. Ohta, M. et al. (2001) Repression domains of class II ERF transcriptional repressors share an essential motif for active repression. Plant Cell 13, 1959-1968

22. Causier, B. et al. (2012) The TOPLESS interactome: a framework for gene repression in Arabidopsis. Plant Physiol. 158, 423-438

23. Krogan, N.T. and Long, J.A. (2009) Why so repressed? Turning off transcription during plant growth and development. Curr. Opin. Plant Biol. 12, 628-636

24. Ma, H. et al. (2017) A D53 repression motif induces oligomerization of TOPLESS corepressors and promotes assembly of a corepressor-nucleosome complex. Sci. Adv. 3, e1601217

25. Acosta, I.F. et al. (2013) Role of NINJA in root jasmonate signaling. Proc. Natl. Acad. Sci. USA 110, 15473-15478

26. Gasperini, D. et al. (2015) Multilayered organization of jasmonate signalling in the regulation of root growth. PLoS Genet. 11, e1005300

27. Kagale, S. et al. (2010) Genome-wide analysis of ethylene-responsive element binding factor-associated amphiphilic repression motif-containing transcriptional regulators in Arabidopsis. Plant Physiol. 152, 1109-1134

28. Kagale, S. and Rozwadowski, K. (2010) Small yet effective: the ethylene responsive element binding factor-associated amphiphilic repression (EAR) motif. Plant Signal. Behav. 5, 691694

29. Raissig, M.T. et al. (2017) Mobile MUTE specifies subsidiary cells to build physiologically improved grass stomata. Science 355, 1215-1218

30. Shyu, C. et al. (2012) JAZ8 lacks a canonical degron and has an EAR motif that mediates transcriptional repression of jasmonate responses in Arabidopsis. Plant Cell 24, 536-550 
31. Li, C. et al. (2020) Arabidopsis ECAP is a new adaptor protein that connects JAZ repressors with the TPR2 co-repressor to suppress jasmonate-responsive anthocyanin accumulation. Mol. Plant DOI: 10.1016/j.molp.2019.10.014

32. Fonseca, S. et al. (2009) (+)-7-iso-Jasmonoyl-L-isoleucine is the endogenous bioactive jasmonate. Nat. Chem. Biol. 5, 344-350

33. Yan, Y. et al. (2007) A downstream mediator in the growth repression limb of the jasmonate pathway. Plant Cell 19, 2470-2483

34. Thines, B. et al. (2007) JAZ repressor proteins are targets of the SCF ${ }^{\mathrm{CO} 11}$ complex during jasmonate signalling. Nature 448, 661-665

35. Sheard, L.B. et al. (2010) Jasmonate perception by inositol-phosphate-potentiated COI1-JAZ co-receptor. Nature 468, 400-405

36. Chini, A. et al. (2007) The JAZ family of repressors is the missing link in jasmonate signalling. Nature 448, 666-671

37. Melotto, M. et al. (2008) A critical role of two positively charged amino acids in the Jas motif of Arabidopsis JAZ proteins in mediating coronatine- and jasmonoyl isoleucine-dependent interactions with the COI1 F-box protein. Plant J. 55, 979-988

38. Chung, H.S. et al. (2010) Alternative splicing expands the repertoire of dominant JAZ repressors of jasmonate signaling. Plant J. 63, 613-622

39. Major, I.T. et al. (2017) Regulation of growth-defense balance by the JASMONATE ZIMDOMAIN (JAZ)-MYC transcriptional module. New Phytol. 215, 1533-1547

40. Baekelandt, A. et al. (2018) Arabidopsis leaf flatness is regulated by PPD2 and NINJA through repression of CYCLIN D3 genes. Plant Physiol. 178, 217-232

41. Ma, Y. et al. (2018) Genome-wide survey and analysis of the TIFY gene family and its potential role in anthocyanin synthesis in Chinese sand pear (Pyrus pyrifolia). Tree Genet. Genomes 14, 25

42. Liu, Z. et al. (2020) Transcriptional repression of GIF1 by the KIX-PPD-MYC repressor complex controls seed size in Arabidopsis. Nat. Commun. 11, 1846

43. Zhu, Y. et al. (2020) Arabidopsis PEAPODs function with LIKE HETEROCHROMATIN PROTEIN1 to regulate lateral organ growth. J. Integr. Plant Biol. 62, 812-831

44. Oña Chuquimarca, S. et al. (2020) The molecular basis of JAZ-MYC coupling, a proteinprotein interface essential for plant response to stressors. Front. Plant Sci. 11, 1139

45. Gonzalez, N. et al. (2015) A repressor protein complex regulates leaf growth in Arabidopsis. Plant Cell 27, 2273-2287

46. Wang, Z. et al. (2016) SCF ${ }^{\mathrm{SAP}}$ controls organ size by targeting PPD proteins for degradation in Arabidopsis thaliana. Nat. Commun. 7, 11192

47. Li, N. et al. (2018) STERILE APETALA modulates the stability of a repressor protein complex to control organ size in Arabidopsis thaliana. PLoS Genet. 14, e1007218

48. Larkin, J.C. et al. (1997) Epidermal cell fate and patterning in leaves. Plant Cell 9, 1109-1120

49. Bergmann, D.C. and Sack, F.D. (2007) Stomatal development. Annu. Rev. Plant Biol. 58, 163181

50. Pillitteri, L.J. and Torii, K.U. (2012) Mechanisms of stomatal development. Annu. Rev. Plant Biol. 63, 591-614

51. White, D.W.R. (2006) PEAPOD regulates lamina size and curvature in Arabidopsis. Proc. Natl. Acad. Sci. USA 103, 13238-13243 
52. Vatén, A. et al. (2018) Modulation of asymmetric division diversity through cytokinin and SPEECHLESS regulatory interactions in the Arabidopsis stomatal lineage. Dev. Cell 47, 53-66

53. Karidas, P. et al. (2015) The tarani mutation alters surface curvature in Arabidopsis leaves by perturbing the patterns of surface expansion and cell division. J. Exp. Bot. 66, 2107-2122

54. Li, Y. et al. (2008) Control of final seed and organ size by the DA1 gene family in Arabidopsis thaliana. Genes Dev. 22, 1331-1336

55. Vanhaeren, H. et al. (2014) Combining growth-promoting genes leads to positive epistasis in Arabidopsis thaliana. elife 3, e02252

56. Andriankaja, M. et al. (2012) Exit from proliferation during leaf development in Arabidopsis thaliana: a not-so-gradual process. Dev. Cell 22, 64-78

57. Kawade, K. et al. (2013) ANGUSTIFOLIA3 signaling coordinates proliferation between clonally distinct cells in leaves. Curr. Biol. 23, 788-792

58. Autran, D. et al. (2002) Cell numbers and leaf development in Arabidopsis: a functional analysis of the STRUWWELPETER gene. EMBO J. 21, 6036-6049

59. Eloy, N.B. et al. (2012) SAMBA, a plant-specific anaphase-promoting complex/cyclosome regulator is involved in early development and A-type cyclin stabilization. Proc. Natl. Acad. Sci. USA 109, 13853-13858

60. Ge, L. et al. (2016) Increasing seed size and quality by manipulating BIG SEEDS1 in legume species. Proc. Natl. Acad. Sci. USA 113, 12414-12419

61. Yin, P. et al. (2020) SMALL LEAF AND BUSHY1 controls organ size and lateral branching by modulating the stability of BIG SEEDS1 in Medicago truncatula. New Phytol. DOI: 10.1111/nph.16449

62. Naito, K. et al. (2017) Multiple organ gigantism caused by mutation in VmPPD gene in blackgram (Vigna mungo). Breed. Sci. 67, 151-158

63. Li, X. et al. (2019) BIGGER ORGANS and ELEPHANT EAR-LIKE LEAF1 control organ size and floral organ internal asymmetry in pea. J. Exp. Bot. 70, 179-191

64. Kanazashi, Y. et al. (2018) Simultaneous site-directed mutagenesis of duplicated loci in soybean using a single guide RNA. Plant Cell Rep. DOI: 10.1007/s00299-018-2251-3

65. Nguyen, C.X. et al. (2020) GmKIX8-1 regulates organ size in soybean and is the causative gene for the major seed weight QTL qSw17-1. New Phytol. in press (doi: 10.1111/nph.16928)

66. Sicard, A. et al. (2016) Standing genetic variation in a tissue-specific enhancer underlies selfing-syndrome evolution in Capsella. Proc. Natl. Acad. Sci. USA 113, 13911-13916

67. Yang, L. et al. (2018) LITTLELEAF (LL) encodes a WD40 repeat domain-containing protein associated with organ size variation in cucumber. Plant J. 95, 834-847

68. Yordanov, Y.S. et al. (2017) BIG LEAF is a regulator of organ size and adventitious root formation in poplar. PLOS ONE 12, e0180527

69. Swinnen, G. et al. (2020) KIX8 and KIX9 are conserved repressors of organ size in the asterid species tomato. bioRxiv, 2020.2002.2007.938977

70. Kim, J.H. and Kende, H. (2004) A transcriptional coactivator, AtGIF1, is involved in regulating leaf growth and morphology in Arabidopsis. Proc. Natl. Acad. Sci. USA 101, 13374-13379

71. Horiguchi, G. et al. (2005) The transcription factor AtGRF5 and the transcription coactivator AN3 regulate cell proliferation in leaf primordia of Arabidopsis thaliana. Plant J. 43, 68-78 
72. Lee, B.H. et al. (2009) The Arabidopsis GRF-INTERACTING FACTOR gene family performs an overlapping function in determining organ size as well as multiple developmental properties. Plant Physiol. 151, 655-668

73. Ercoli, M.F. et al. (2018) GIF transcriptional coregulators control root meristem homeostasis. Plant Cell 30, 347-359

74. Kanei, M. et al. (2012) Stable establishment of cotyledon identity during embryogenesis in Arabidopsis by ANGUSTIFOLIA3 and HANABA TARANU. Development 139, 2436-2446

75. Lee, B.H. et al. (2014) The Arabidopsis thaliana GRF-INTERACTING FACTOR gene family plays an essential role in control of male and female reproductive development. Dev. Biol. 386, $12-24$

76. Vercruyssen, L. et al. (2015) GROWTH REGULATING FACTOR5 stimulates Arabidopsis chloroplast division, photosynthesis, and leaf longevity. Plant Physiol. 167, 817-832

77. Vercruyssen, L. et al. (2014) ANGUSTIFOLIA3 binds to SWI/SNF chromatin remodeling complexes to regulate transcription during Arabidopsis leaf development. Plant Cell 26, 210229

78. Zhang, F. et al. (2019) Control of leaf blade outgrowth and floral organ development by LEUNIG, ANGUSTIFOLIA3 and WOX transcriptional regulators. New Phytol. 223, 2024-2038

79. Husbands, A.Y. et al. (2015) The ASYMMETRIC LEAVES complex employs multiple modes of regulation to affect adaxial-abaxial patterning and leaf complexity. Plant Cell 27, 3321-3335

80. Byrne, M.E. et al. (2000) Asymmetric leaves1 mediates leaf patterning and stem cell function in Arabidopsis. Nature 408, 967-971

81. Kalve, S. et al. (2014) Leaf development: a cellular perspective. Front. Plant Sci. 5, 362

82. Martienssen, R.A. (2000) Weeding out the genes: the Arabidopsis genome project. Funct. Integr. Genomics 1, 2-11

83. White, D.W.R. (2017) PEAPOD limits developmental plasticity in Arabidopsis. bioRxiv DOI: $10.1101 / 102707$

84. Winter, D. et al. (2007) An "electronic Fluorescent Pictograph" browser for exploring and analyzing large-scale biological data sets. PLOS ONE 2, e718

85. Ferjani, A. et al. (2007) Analysis of leaf development in fugu mutants of Arabidopsis reveals three compensation modes that modulate cell expansion in determinate organs. Plant Physiol. 144, 988-999

86. Meng, L.-S. et al. (2016) Seed embryo development is regulated via an AN3-MINI3 gene cascade. Front. Plant Sci. 7, 1645

87. Jiang, W.-B. et al. (2013) Brassinosteroid regulates seed size and shape in Arabidopsis. Plant Physiol. 162, 1965-1977

88. Choe, S. et al. (2001) Overexpression of DWARF4 in the brassinosteroid biosynthetic pathway results in increased vegetative growth and seed yield in Arabidopsis. Plant J. 26, 573-582

89. Kim, H.B. et al. (2006) The regulation of DWARF4 expression is likely a critical mechanism in maintaining the homeostasis of bioactive brassinosteroids in Arabidopsis. Plant Physiol. 140, 548-557

90. Wang, Z.-Y. et al. (2001) BRI1 is a critical component of a plasma-membrane receptor for plant steroids. Nature 410, 380-383 
91. Oh, M.-H. et al. (2012) Deactivation of the Arabidopsis BRASSINOSTEROID INSENSITIVE 1 (BRI1) receptor kinase by autophosphorylation within the glycine-rich loop. Proc. Natl. Acad. Sci. USA 109, 327-332

92. Gonzalez, N. et al. (2010) Increased leaf size: different means to an end. Plant Physiol. 153, 1261-1279

93. Donnelly, P.M. et al. (1999) Cell cycling and cell enlargement in developing leaves of Arabidopsis. Dev. Biol. 215, 407-419

94. De Rybel, B. et al. (2014) Integration of growth and patterning during vascular tissue formation in Arabidopsis. Science 345, 1255215

95. De Rybel, B. et al. (2016) Plant vascular development: from early specification to differentiation. Nat. Rev. Mol. Cell Biol. 17, 30-40

96. Lucas, W.J. et al. (2013) The plant vascular system: evolution, development and functions. J. Integr. Plant Biol. 55, 294-388

97. Ohashi-Ito, K. and Fukuda, H. (2014) Initiation of vascular development. Physiol. Plant. 151, 142-146

98. De Rybel, B. et al. (2013) A bHLH complex controls embryonic vascular tissue establishment and indeterminate growth in Arabidopsis. Dev. Cell 24, 426-437

99. Ohashi-Ito, K. and Bergmann, D.C. (2007) Regulation of the Arabidopsis root vascular initial population by LONESOME HIGHWAY. Development 134, 2959-2968

100. Ohashi-Ito, K. et al. (2014) A bHLH complex activates vascular cell division via cytokinin action in root apical meristem. Curr. Biol. 24, 2053-2058

101. Katayama, H. et al. (2015) A negative feedback loop controlling bHLH complexes is involved in vascular cell division and differentiation in the root apical meristem. Curr. Biol. 25, 31443150

102. Vera-Sirera, F. et al. (2015) A bHLH-based feedback loop restricts vascular cell proliferation in plants. Dev. Cell 35, 432-443

103. Yamamoto, M. and Takahashi, T. (2017) Thermospermine enhances translation of SAC51 and SACL1 in Arabidopsis. Plant Signal. Behav. 12, e1276685

104. Clay, N.K. and Nelson, T. (2005) Arabidopsis thickvein mutation affects vein thickness and organ vascularization, and resides in a provascular cell-specific spermine synthase involved in vein definition and in polar auxin transport. Plant Physiol. 138, 767-777

105. Kinoshita, A. and Richter, R. (2020) Genetic and molecular basis of floral induction in Arabidopsis thaliana. J. Exp. Bot. DOI: 10.1093/jxb/eraa057

106. Mathieu, J. et al. (2009) Repression of flowering by the miR172 target SMZ. PLoS Biol. 7, e1000148

107. Cao, S. et al. (2014) A distal CCAAT/NUCLEAR FACTOR Y complex promotes chromatin looping at the FLOWERING LOCUS T promoter and regulates the timing of flowering in Arabidopsis. Plant Cell 26, 1009-1017

108. Zhai, Q. et al. (2015) Transcriptional mechanism of jasmonate receptor COI1-mediated delay of flowering time in Arabidopsis. Plant Cell 27, 2814-2828

109. Zhang, B. et al. (2015) Arabidopsis TOE proteins convey a photoperiodic signal to antagonize CONSTANS and regulate flowering time. Genes Dev. 29, 975-987

110. Jung, J.-H. et al. (2007) The GIGANTEA-regulated microRNA172 mediates photoperiodic flowering independent of CONSTANS in Arabidopsis. Plant Cell 19, 2736-2748 
111. Zuo, Z. et al. (2011) Blue light-dependent interaction of CRY2 with SPA1 regulates COP1 activity and floral initiation in Arabidopsis. Curr. Biol. 21, 841-847

112. Usadel, B. et al. (2006) PageMan: an interactive ontology tool to generate, display, and annotate overview graphs for profiling experiments. BMC Bioinformatics 7, 535

113. Nakazawa, M. et al. (2001) DFL1, an auxin-responsive GH3 gene homologue, negatively regulates shoot cell elongation and lateral root formation, and positively regulates the light response of hypocotyl length. Plant J. 25, 213-221

114. Staswick, P. (2009) Plant hormone conjugation: a signal decision. Plant Signal. Behav. 4, 757759

115. Staswick, E. et al. (2005) Characterization of an Arabidopsis enzyme family that conjugates amino acids to indole-3-acetic acid. Plant Cell 17, 616-627

116. Gutierrez, L. et al. (2012) Auxin controls Arabidopsis adventitious root initiation by regulating jasmonic acid homeostasis. Plant Cell 24, 2515-2527

117. Han, G.-Z. (2017) Evolution of jasmonate biosynthesis and signaling mechanisms. J. Exp. Bot. $68,1323-1331$

118. Tsukaya, H. et al. (2002) Genetic control of petiole length in Arabidopsis thaliana. Plant Cell Physiol. 43, 1221-1228

119. Kozuka, T. et al. (2005) The different growth responses of the Arabidopsis thaliana leaf blade and the petiole during shade avoidance are regulated by photoreceptors and sugar. Plant Cell Physiol. 46, 213-223

120. Harmon, F.G. and Kay, S.A. (2003) The F box protein AFR is a positive regulator of phytochrome A-mediated light signaling. Curr. Biol. 13, 2091-2096

121. Huang, Z. et al. (2016) Genome-wide identification and characterization of TIFY family genes in Moso Bamboo (Phyllostachys edulis) and expression profiling analysis under dehydration and cold stresses. PeerJ 4, e2620

122. Zhang, L. et al. (2015) Identification and characterization of TIFY family genes in Brachypodium distachyon. J. Plant Res. 128, 995-1005

123. Zhang, Z. et al. (2015) Isolation, structural analysis, and expression characteristics of the maize TIFY gene family. Mol. Genet. Genomics 290, 1849-1858

124. Saha, G. et al. (2016) A genome-wide analysis reveals stress and hormone responsive patterns of TIFY family genes in Brassica rapa. Front. Plant Sci. 7, 936

125. Zhu, D. et al. (2013) Identification of wild soybean (Glycine soja) TIFY family genes and their expression profiling analysis under bicarbonate stress. Plant Cell Rep. 32, 263-272

126. Liu, F. et al. (2017) Plant jasmonate ZIM domain genes: shedding light on structure and expression patterns of $J A Z$ gene family in sugarcane. BMC Genomics 18, 771

127. Sun, Q. et al. (2017) Genome-wide identification of the TIFY gene family in three cultivated Gossypium species and the expression of JAZ genes. Sci. Rep. 7, 42418

128. Liu, T. et al. (2009) Orthologs of Arabidopsis thaliana stomatal bHLH genes and regulation of stomatal development in grasses. Development 136, 2265-2276

129. Peterson, K.M. et al. (2010) Out of the mouths of plants: the molecular basis of the evolution and diversity of stomatal development. Plant Cell 22, 296-306

130. Nelson, T. and Dengler, N. (1997) Leaf vascular pattern formation. Plant Cell 9, 1121-1135

131. Vatén, A. and Bergmann, D.C. (2012) Mechanisms of stomatal development: an evolutionary view. EvoDevo 3, 11 
132. Zhuang, L.-L. et al. (2012) LATHYROIDES, encoding a WUSCHEL-related Homeobox1 transcription factor, controls organ lateral growth, and regulates tendril and dorsal petal identities in garden pea (Pisum sativum L.). Mol. Plant 5, 1333-1345

133. Wang, H. et al. (2017) Overexpression of the WOX gene STENOFOLIA improves biomass yield and sugar release in transgenic grasses and display altered cytokinin homeostasis. PLoS Genet. 13, e1006649

134. Liu, M. et al. (2018) The STENOFOLIA gene from Medicago alters leaf width, flowering time and chlorophyll content in transgenic wheat. Plant Biotechnol. J. 16, 186-196

135. Nakata, M. et al. (2012) Roles of the middle domain-specific WUSCHEL-RELATED HOMEOBOX genes in early development of leaves in Arabidopsis. Plant Cell 24, 519-535

136. Tadege, M. et al. (2011) Control of dicot leaf blade expansion by a WOX gene, STF. Plant Signal. Behav. 6, 1861-1864

137. Tadege, M. et al. (2011) STENOFOLIA regulates blade outgrowth and leaf vascular patterning in Medicago truncatula and Nicotiana sylvestris. Plant Cell 23, 2125-2142

138. Nardmann, J. et al. (2004) The maize duplicate genes narrow sheath1 and narrow sheath2 encode a conserved homeobox gene function in a lateral domain of shoot apical meristems. Development 131, 2827-2839

139. Nardmann, J. et al. (2007) WOX gene phylogeny in Poaceae: a comparative approach addressing leaf and embryo development. Mol. Biol. Evol. 24, 2474-2484

140. Cho, S.-H. et al. (2013) The rice narrow leaf2 and narrow leaf3 loci encode WUSCHEL-related homeobox 3A (OsWOX3A) and function in leaf, spikelet, tiller and lateral root development. New Phytol. 198, 1071-1084

141. Yoshikawa, T. et al. (2016) Barley NARROW LEAFED DWARF1 encoding a WUSCHEL-RELATED HOMEOBOX 3 (WOX3) regulates the marginal development of lateral organs. Breed. Sci. 66, 416-424

142. Van Bel, M. et al. (2018) PLAZA 4.0: an integrative resource for functional, evolutionary and comparative plant genomics. Nucleic Acids Res. 46, D1190-D1196

143. Pickersgill, B. (2007) Domestication of plants in the Americas: insights from mendelian and molecular genetics. Ann. Bot. 100, 925-940

144. Jorasch, P. (2019) The global need for plant breeding innovation. Transgenic Res. 28, 81-86

145. Swinnen, G. et al. (2016) Lessons from domestication: targeting cis-regulatory elements for crop improvement. Trends Plant Sci. 21, 506-515

146. Doebley, J.F. et al. (2006) The molecular genetics of crop domestication. Cell 127, 1309-1321

147. Meyer, R.S. and Purugganan, M.D. (2013) Evolution of crop species: genetics of domestication and diversification. Nat. Rev. Genet. 14, 840-852

148. Li, Q. et al. (2020) Perspectives of CRISPR/Cas-mediated cis-engineering in horticulture: unlocking the neglected potential for crop improvement. Hortic. Res. 7, 36

149. Rodríguez-Leal, D. et al. (2017) Engineering quantitative trait variation for crop improvement by genome editing. Cell 171, 470-480.e478

150. Feng, Z. et al. (2013) Efficient genome editing in plants using a CRISPR/Cas system. Cell Res. 23, 1229-1232

151. Fauser, F. et al. (2014) Both CRISPR/Cas-based nucleases and nickases can be used efficiently for genome engineering in Arabidopsis thaliana. Plant J. 79, 348-359 
152. Li, S. et al. (2016) The OsmiR396c-OsGRF4-OsGIF1 regulatory module determines grain size and yield in rice. Plant Biotechnol. J. 14, 2134-2146

153. He, Z. et al. (2017) OsGIF1 positively regulates the sizes of stems, leaves, and grains in rice. Front. Plant Sci. 8, 1730

\section{Outstanding Questions Box}

- What are the structural and molecular differences between PPD and JAZ proteins enabling their involvement in different processes, despite their striking similarities?

- If the PPD/KIX/NINJA complex acts as a general adaptor complex, with which additional transcriptional regulators does it interact and does this occur in a process-, tissue- and/or cell-specific manner?

- What is the individual contribution of PPD1, PPD2, KIX8 and KIX9 in specific processes? This will require to interrogate their expression patterns at a high spatiotemporal resolution, putatively uncovering their tissue-specific interaction behaviour and/or their involvement in yet unexplored processes.

- How is SAP activity regulated and what triggers the SAP-mediated proteasome-dependent degradation of the PPD/KIX complex? Is there a ligand or trigger and is this then developmental, hormonal and/or based on environmental stimuli?

- Under which circumstances does crosstalk between the PPD pathway and light and hormone signalling occur and what is its biological relevance in a developmental and/or environmental context?

- What is the contribution of the PPD/KIX/SAP module to processes unexplored so far, such as flowering time and vascular development?

- Which mechanisms are involved in the transcriptional regulation of the PPD/KIX/SAP module and how could this be exploited for biotechnological applications?

- The PPD/KIX/SAP module is lost in Poaceae (monocot grasses), though retained in several non-grass monocot species as well as in the basal angiosperm Amborella trichopoda and even lycophytes, suggesting its involvement in processes that are intrinsically different in grasses. Which are these processes and are the functions of PPD/KIX/SAP orthologues retained in non-monocot grasses and more basal plants? 
Figures 
(A)

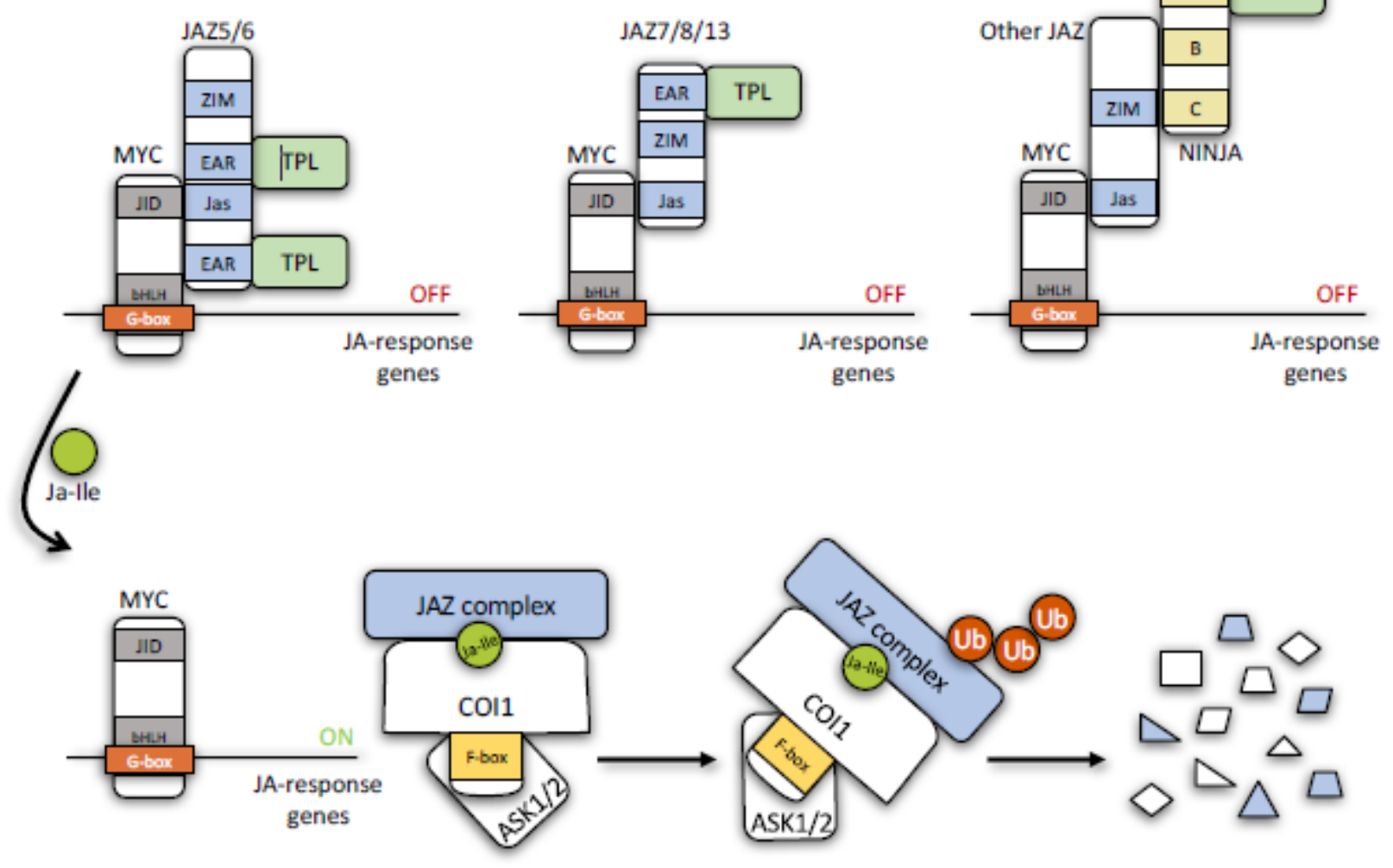

(B)
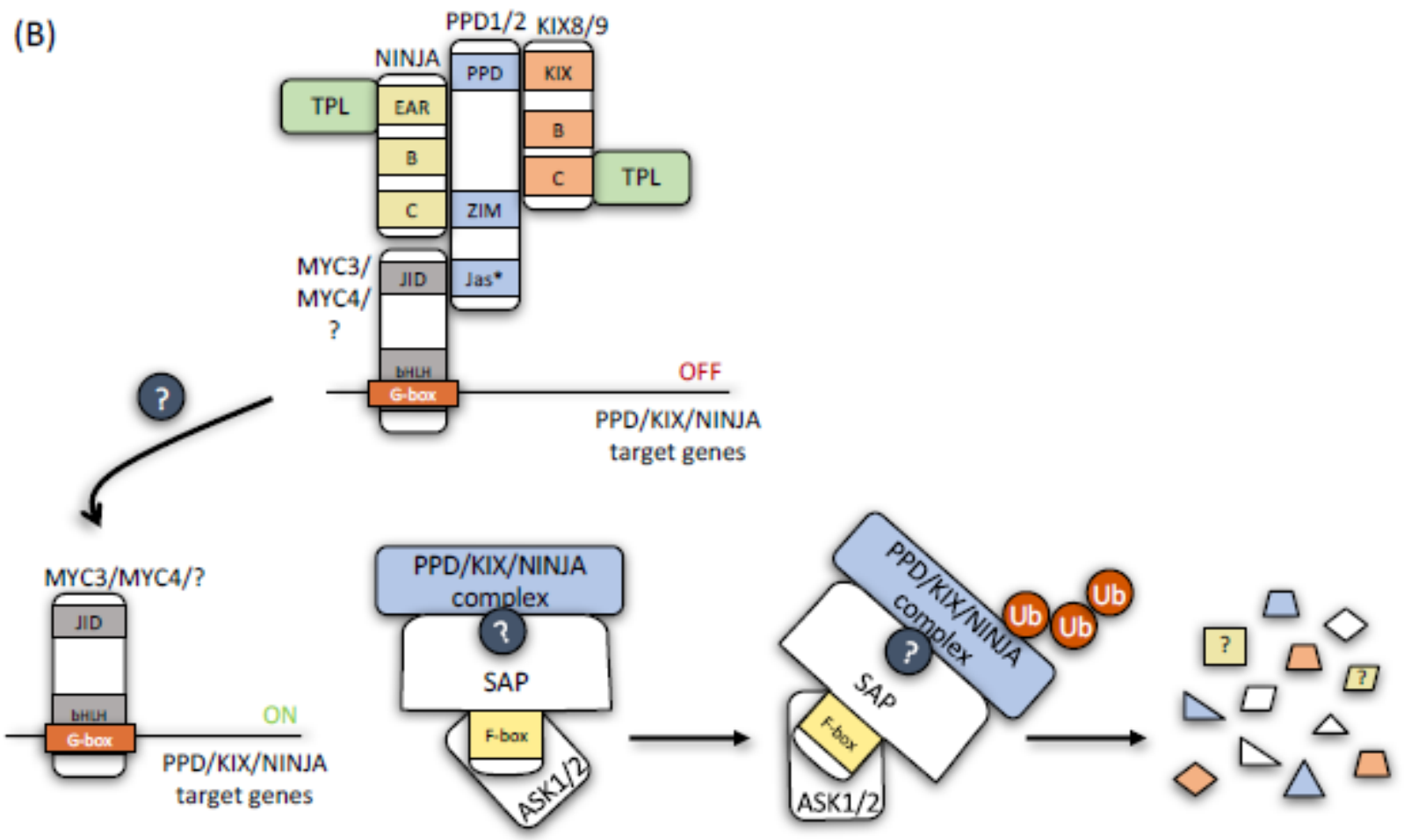
Figure 1. Similarities and Differences Between JAZ and PPD Proteins and Their Interaction Network. (A) In the absence of jasmonic acid (JA), JASMONATE ZIM DOMAIN (JAZ) proteins bind with MYC and R2R3 MYB transcription factors through their Jas domain and recruit the corepressor TOPLESS (TPL) through their ETHYLENE RESPONSE FACTOR (ERF)-ASSOCIATED AMPHIPHILIC REPRESSION (EAR) motif. JAZ5 to JAZ8 and JAZ13 contain one or multiple EAR motifs and can therefore directly interact with TPL. The other arabidopsis JAZ proteins lack an EAR motif and recruit TPL by binding with their ZINC-FINGER PROTEIN EXPRESSED IN INFLORESCENCE MERISTEM (ZIM) domain to the EAR motif-containing protein NOVEL INTERACTOR OF JAZ (NINJA). In all cases, this results in the repression of JA-response genes. Upon perception of JA-isoleucine (JA-Ile), the JAZ protein complex is poly-ubiquitinated by the F-box protein CORONATINE INSENSITIVE 1 (COI1)-containing SKP1/CULLIN1/F-BOX PROTEIN (SCF) E3 ubiquitin ligase complex, resulting in its degradation and the induction of the downstream JA-transcriptional response by JAZ-bound transcription factors. (B) PEAPOD (PPD) proteins have a specific PPD domain, that mediates the interaction with KINASE-INDUCIBLE DOMAIN INTERACTING PROTEIN 8/9 (KIX8/9), and a ZIM domain that interacts with NINJA, both recruiting TPL. Also the basic HELIX-LOOP-HELIX (bHLH) transcription factors MYC3 and MYC4 and potential other yet unidentified transcriptional regulators are recruited to the complex (MYC3/MYC4/?), likely via their slightly convergent Jas domain (Jas*). Poly-ubiquitination of the PPD/KIX complex by the F-box protein STERILE APETALA (SAP)-containing SCF complex, upon perception of a yet unknown signal (question mark), results in proteasome-dependent degradation of the PPD/KIX complex. Currently, it is unknown whether also NINJA is prone to SAP-mediated proteasome-dependent degradation (questions marks). 


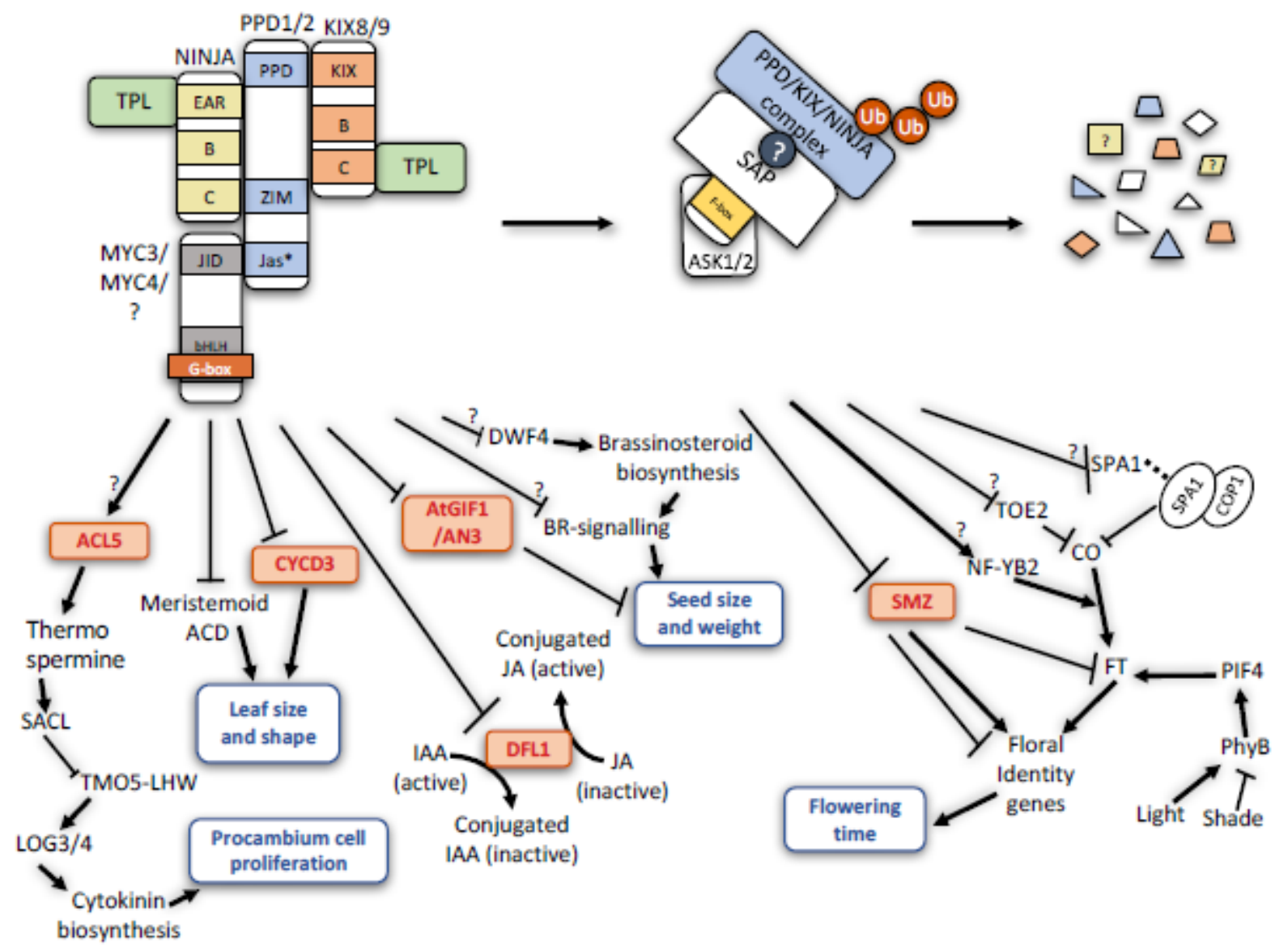

Figure 2. Schematic Overview of the PPD Pathway and Putative Connections with Developmental, Hormonal and Light Pathways. The PPD and ZIM domains of PEAPOD (PPD) proteins interact with KINASE-INDUCIBLE DOMAIN INTERACTING PROTEIN 8/9 (KIX8/9) and NOVEL INTERACTOR OF JAZ (NINJA), respectively, recruiting TOPLESS (TPL). Also the basic HELIXLOOP-HELIX (bHLH) transcription factors MYC3 and MYC4 and potential other yet unidentified transcriptional regulators are recruited to the complex (MYC3/MYC4/?), likely via their slightly convergent Jas domain (Jas*). The protein complex directly represses the expression of distinct downstream target genes (red), including DWARF IN LIGHT 1 (DFL1), SCHLAFMUTZE (SMZ), CYCLIN D3s (CYCD3) and Arabidopsis thaliana GRF-INTERACTING PROTEIN 1 (AtGIF1)/ANGUSTIFOLIA3 (AN3), to regulate distinct biological processes (blue). Also several other genes are proposed to be regulated by the PPD/KIX complex, including ACAULIS 5 (ACL5), DWARF 4 (DWF4), NUCLEAR FACTOR Y SUBUNIT B2 (NF-YB2), TARGET OF EARLY ACTIVATED TAGGED 2 (TOE2) and SUPPRESSOR OF PHYTOCHROME A-105 1 (SPA1), though not yet validated (question marks). Poly- 
ubiquitination of the PPD/KIX complex by the F-box protein STERILE APETALA (SAP)-containing SKP1/CULLIN1/F-BOX PROTEIN (SCF) complex results in its proteasome-dependent degradation. Currently, it is unknown whether also NINJA is prone to SAP-mediated proteasome-dependent degradation (questions marks). Abbreviations: ACD, asymmetric cell division; CO, CONSTANS; COP1, CONSTITUTIVE PHOTOMORPHOGENIC 1; FT, FLOWERING LOCUS T; IAA, indole-3-acetic acid; LOG, LONELY GUY; LHW, LONESOME HIGHWAY; phyB, PHYTOCHROME B; SACL, SUPPRESSOR OF ACAULIS-LIKE; TMO5, TARGET GENE OF MONOPTEROS 5. 


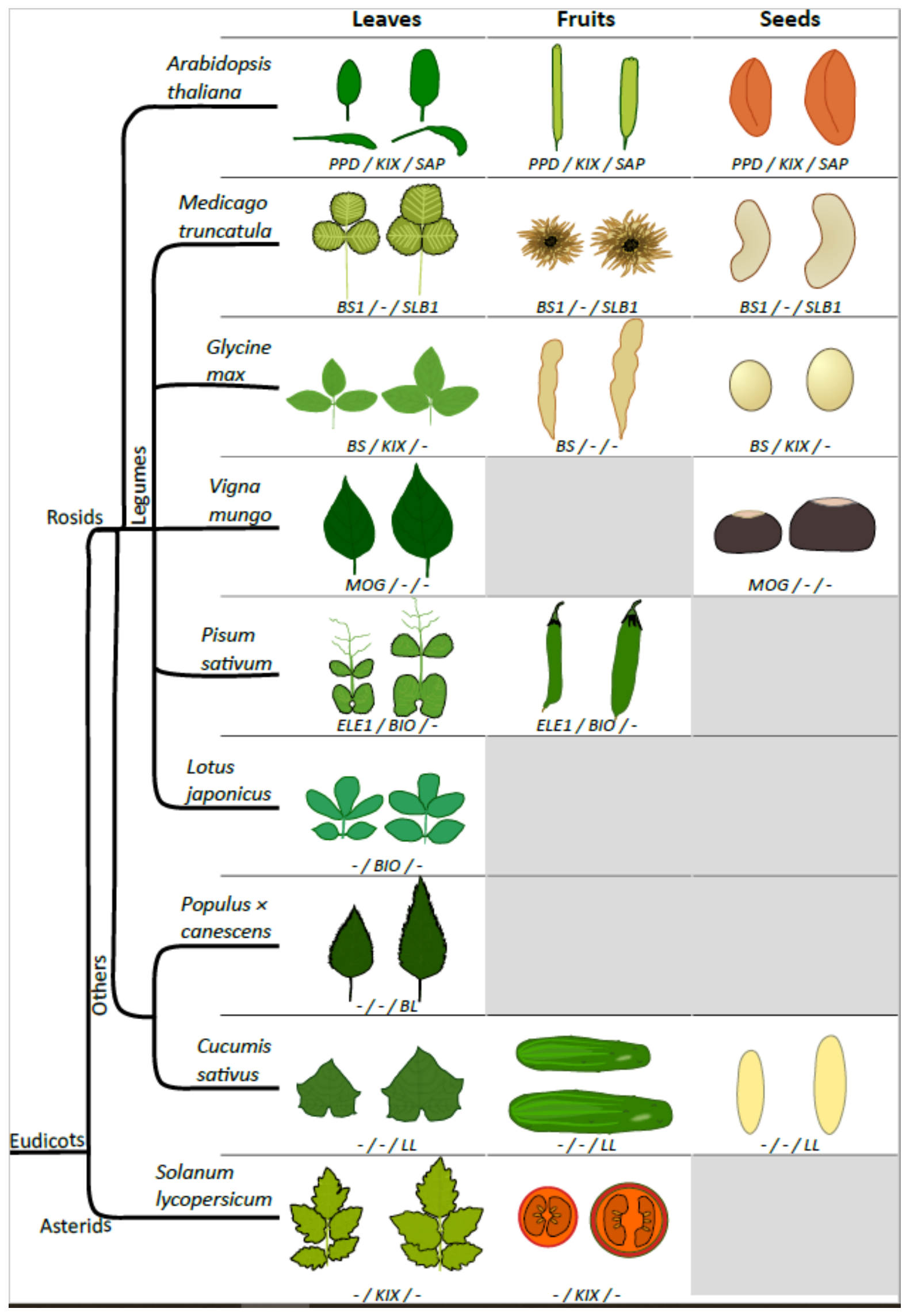


Figure 3. Organ Size Changes by Targeting the PPD/KIX/SAP Module in Various Plant Species. Schematic overview of leaf, fruit, and seed size alterations upon down-regulation of $P P D$ and KIX or up-regulation of SAP or their respective orthologues in different plant species (PPD/KIX/SAP), unless no phenotype is reported for the respective orthologue (indicated by ' ${ }^{\prime}$ ). In each category, a representation of the wild-type and mutant organs is presented on the left and the right, respectively, except for the Cucumis sativus fruit, where the wild-type and the mutant organ is presented at the top and the bottom, respectively. Grey fields indicate that the effect of targeting the PPD/KIX/SAP module is currently unknown or irrelevant for the respective organ. The references corresponding to the phenotypes shown can be found in Table 1. PEAPOD (PPD); PPD orthologues: BIG SEEDS (BS); MULTIPLE ORGAN GIGANTISM (MOG); ELEPHANT-EAR-LIKE LEAF 1 (ELE1). KINASE-INDUCIBLE DOMAIN INTERACTING (KIX); KIX orthologue: BIGGER ORGANS (BIO). STERILE APETALA (SAP); SAP orthologues: SMALL LEAF AND BUSHY 1 (SLB1); BIG LEAF (BL); LITTLELEAF (LL). 
Table 1. Overview of PPD/KIX/SAP Mutant Phenotypes in Different Eudicot Species ${ }^{\text {a }}$

\begin{tabular}{|c|c|c|c|c|c|c|c|}
\hline $\begin{array}{l}\text { Gene } \\
\text { name }\end{array}$ & $\begin{array}{l}\text { Arabidopsis } \\
\text { thaliana } \\
\text { orthologue }\end{array}$ & Organism & Type & $\begin{array}{l}\text { Shoot/leaf } \\
\text { size } \\
\text { phenotype }\end{array}$ & $\begin{array}{l}\text { Seed/fruit } \\
\text { phenotype }\end{array}$ & $\begin{array}{l}\text { Additional } \\
\text { phenotypes }\end{array}$ & Refs. \\
\hline PPD1 & PPD1 & $\begin{array}{l}\text { Arabidopsis } \\
\text { thaliana }\end{array}$ & LOF & $\begin{array}{l}\text { no } \\
\text { difference }\end{array}$ & no difference & & {$[42,43,51,83]$} \\
\hline PPD1 & PPD1 & $\begin{array}{l}\text { Arabidopsis } \\
\text { thaliana }\end{array}$ & GOF & decreased & $\begin{array}{l}\text { shorter, } \\
\text { narrower, } \\
\text { flatter siliques }\end{array}$ & $\begin{array}{l}\text { reduced vascular } \\
\text { system }\end{array}$ & {$[51,83]$} \\
\hline PPD2 & PPD2 & $\begin{array}{l}\text { Arabidopsis } \\
\text { thaliana }\end{array}$ & LOF & increased & $\begin{array}{l}\text { slightly } \\
\text { increased }\end{array}$ & & {$[40,43,51,83]$} \\
\hline PPD2 & PPD2 & $\begin{array}{l}\text { Arabidopsis } \\
\text { thaliana }\end{array}$ & GOF & decreased & decreased & $\begin{array}{l}\text { reduced number } \\
\text { of stomata, } \\
\text { reduced vascular } \\
\text { network, } \\
\text { shortened primary } \\
\text { roots }\end{array}$ & {$[43,51,83]$} \\
\hline $\begin{array}{l}P P D 1 / P P \\
D 2\end{array}$ & PPD1/PPD2 & $\begin{array}{l}\text { Arabidopsis } \\
\text { thaliana }\end{array}$ & LOF & increased & increased & $\begin{array}{l}\text { increased number } \\
\text { of guard and } \\
\text { pavement cells, } \\
\text { increased vascular } \\
\text { network, delayed } \\
\text { flowering }\end{array}$ & {$[40,42,43,45,51,83]$} \\
\hline KIX8 & KIX8 & $\begin{array}{l}\text { Arabidopsis } \\
\text { thaliana }\end{array}$ & LOF & $\begin{array}{l}\text { no } \\
\text { difference }\end{array}$ & $\begin{array}{l}\text { slightly } \\
\text { increased }\end{array}$ & & {$[42,45]$} \\
\hline KIX9 & KIX9 & $\begin{array}{l}\text { Arabidopsis } \\
\text { thaliana }\end{array}$ & LOF & $\begin{array}{l}\text { no } \\
\text { difference }\end{array}$ & no difference & & {$[42,45]$} \\
\hline $\begin{array}{l}K I X 8 / K I X \\
9\end{array}$ & KIX8/KIX9 & $\begin{array}{l}\text { Arabidopsis } \\
\text { thaliana }\end{array}$ & LOF & increased & increased & $\begin{array}{l}\text { increased number } \\
\text { of hypocotyl guard } \\
\text { cells, delayed } \\
\text { flowering, } \\
\text { elongated } \\
\text { hypocotyls }\end{array}$ & {$[42,45,83]$} \\
\hline NINJA & NINJA & $\begin{array}{l}\text { Arabidopsis } \\
\text { thaliana }\end{array}$ & LOF & $\begin{array}{l}\text { no } \\
\text { difference }\end{array}$ & & & [40] \\
\hline NINJA & NINJA & $\begin{array}{l}\text { Arabidopsis } \\
\text { thaliana }\end{array}$ & GOF & & & $\begin{array}{l}\text { decreased JA } \\
\text { sensitivty }\end{array}$ & [20] \\
\hline MYC3 & MYC3 & $\begin{array}{l}\text { Arabidopsis } \\
\text { thaliana }\end{array}$ & LOF & & increased & & [42] \\
\hline MYC4 & MYC4 & $\begin{array}{l}\text { Arabidopsis } \\
\text { thaliana }\end{array}$ & LOF & & increased & & [42] \\
\hline $\begin{array}{l}\text { SAP } \\
\text { (SOD3) }\end{array}$ & SAP (SOD3) & $\begin{array}{l}\text { Arabidopsis } \\
\text { thaliana }\end{array}$ & LOF & decreased & & $\begin{array}{l}\text { small or absent } \\
\text { flowers or flower } \\
\text { parts }\end{array}$ & {$[42,46,47]$} \\
\hline $\begin{array}{l}\text { SAP } \\
\text { (SOD3) }\end{array}$ & SAP (SOD3) & $\begin{array}{l}\text { Arabidopsis } \\
\text { thaliana }\end{array}$ & GOF & increased & increased & larger flowers & {$[42,46,47]$} \\
\hline
\end{tabular}




\begin{tabular}{|c|c|c|c|c|c|c|c|}
\hline $\begin{array}{l}\text { Gene } \\
\text { name }\end{array}$ & $\begin{array}{l}\text { Arabidopsis } \\
\text { thaliana } \\
\text { orthologue }\end{array}$ & Organism & Type & $\begin{array}{l}\text { Shoot/leaf } \\
\text { size } \\
\text { phenotype }\end{array}$ & $\begin{array}{l}\text { Seed/fruit } \\
\text { phenotype }\end{array}$ & $\begin{array}{l}\text { Additional } \\
\text { phenotypes }\end{array}$ & Refs. \\
\hline CYCD3;2 & $C Y C D 3 ; 2$ & $\begin{array}{l}\text { Arabidopsis } \\
\text { thaliana }\end{array}$ & GOF & $\begin{array}{l}\text { no } \\
\text { difference }\end{array}$ & & $\begin{array}{l}\text { reduced stomatal } \\
\text { index }\end{array}$ & [40] \\
\hline CYCD3;3 & $C Y C D 3 ; 3$ & $\begin{array}{l}\text { Arabidopsis } \\
\text { thaliana }\end{array}$ & GOF & decreased & & & [40] \\
\hline $\begin{array}{l}\text { AtGIF1/ } \\
\text { AN3 }\end{array}$ & AtGIF1/AN3 & $\begin{array}{l}\text { Arabidopsis } \\
\text { thaliana }\end{array}$ & GOF & increased & increased & & {$[42,71]$} \\
\hline $\begin{array}{l}\text { AtGIF1/ } \\
\text { AN3 }\end{array}$ & AtGIF1/AN3 & $\begin{array}{l}\text { Arabidopsis } \\
\text { thaliana }\end{array}$ & LOF & decreased & $\begin{array}{l}\text { Decreased, } \\
\text { increased in } \\
\text { an3-4 }\end{array}$ & narrow petals & {$[42,70,71,86]$} \\
\hline GRF5 & GRF5 & $\begin{array}{l}\text { Arabidopsis } \\
\text { thaliana }\end{array}$ & GOF & increased & & & [71] \\
\hline GRF5 & GRF5 & $\begin{array}{l}\text { Arabidopsis } \\
\text { thaliana }\end{array}$ & LOF & $\begin{array}{l}\text { slightly } \\
\text { decreased }\end{array}$ & & & [71] \\
\hline wox1 & WOX1 & $\begin{array}{l}\text { Arabidopsis } \\
\text { thaliana }\end{array}$ & LOF & $\begin{array}{l}\text { no } \\
\text { difference }\end{array}$ & & & [135] \\
\hline wox1 & WOX1 & $\begin{array}{l}\text { Arabidopsis } \\
\text { thaliana }\end{array}$ & GOF & decreased & & $\begin{array}{l}\text { dwarfed } \\
\text { phenotype, } \\
\text { disturbed anther } \\
\text { development, } \\
\text { decreased fertility }\end{array}$ & [135] \\
\hline MtSTF & $\begin{array}{l}\text { WOX1 } \\
\text { (WUS/WOX } \\
\text { family) }\end{array}$ & $\begin{array}{l}\text { Brachypodium } \\
\text { distachyon }\end{array}$ & GOF & increased & & $\begin{array}{l}\text { higher number of } \\
\text { leaf veins, thicker } \\
\text { stems }\end{array}$ & [133] \\
\hline CrSAP & SAP & $\begin{array}{l}\text { Capsella } \\
\text { rubella }\end{array}$ & LOF & & & $\begin{array}{l}\text { decreased petal } \\
\text { size }\end{array}$ & [66] \\
\hline CsLL & SAP & $\begin{array}{l}\text { Cucumis } \\
\text { sativus }\end{array}$ & LOF & decreased & decreased & $\begin{array}{l}\text { smaller fruits, } \\
\text { smaller flowers, } \\
\text { increased } \\
\text { branching }\end{array}$ & [67] \\
\hline CsLL & $S A P$ & $\begin{array}{l}\text { Cucumis } \\
\text { sativus }\end{array}$ & GOF & increased & increased & $\begin{array}{l}\text { bigger fruits, } \\
\text { increased flower } \\
\text { size }\end{array}$ & [67] \\
\hline $\begin{array}{l}\text { GmBS1/ } \\
2 \\
(G m P P D \\
1 / 2)\end{array}$ & $P P D$ & Glycine max & LOF & increased & increased & $\begin{array}{l}\text { increased amino } \\
\text { acid content in } \\
\text { seeds, elongated } \\
\text { petioles, increased } \\
\text { ripening period }\end{array}$ & {$[60,62,64]$} \\
\hline $\begin{array}{l}\text { GmKIX8- } \\
1\end{array}$ & KIX8 & Glycine max & LOF & increased & increased & & [65] \\
\hline MtSLB1 & SAP & Glycine max & GOF & increased & increased & & [61] \\
\hline LjBIO & $\begin{array}{l}\text { KIX8/KIX9 } \\
\text { subfamily }\end{array}$ & $\begin{array}{l}\text { Lotus } \\
\text { japonicus }\end{array}$ & LOF & increased & & $\begin{array}{l}\text { disrupted floral } \\
\text { symmetry }\end{array}$ & [63] \\
\hline
\end{tabular}




\begin{tabular}{|c|c|c|c|c|c|c|c|}
\hline $\begin{array}{l}\text { Gene } \\
\text { name }\end{array}$ & $\begin{array}{l}\text { Arabidopsis } \\
\text { thaliana } \\
\text { orthologue }\end{array}$ & Organism & Type & $\begin{array}{l}\text { Shoot/leaf } \\
\text { size } \\
\text { phenotype }\end{array}$ & $\begin{array}{l}\text { Seed/fruit } \\
\text { phenotype }\end{array}$ & $\begin{array}{l}\text { Additional } \\
\text { phenotypes }\end{array}$ & Refs. \\
\hline LjNAO1 & $\begin{array}{l}\text { WOX1 } \\
\text { (WUS/WOX } \\
\text { family) }\end{array}$ & $\begin{array}{l}\text { Lotus } \\
\text { japonicus }\end{array}$ & LOF & & & $\begin{array}{l}\text { small, narrow } \\
\text { petals }\end{array}$ & [63] \\
\hline MtBS1 & $P P D$ & $\begin{array}{l}\text { Medicago } \\
\text { truncatula }\end{array}$ & LOF & increased & increased & $\begin{array}{l}\text { increased flower } \\
\text { size, arrested } \\
\text { axillary bud } \\
\text { outgrowth }\end{array}$ & {$[60,61]$} \\
\hline MtSLB1 & $S A P$ & $\begin{array}{l}\text { Medicago } \\
\text { truncatula }\end{array}$ & LOF & decreased & & $\begin{array}{l}\text { smaller flowers, } \\
\text { increased lateral } \\
\text { branching }\end{array}$ & [61] \\
\hline MtSLB1 & $S A P$ & $\begin{array}{l}\text { Medicago } \\
\text { truncatula }\end{array}$ & GOF & increased & increased & & [61] \\
\hline MtSTF & $\begin{array}{l}\text { WOX1 } \\
\text { (WUS/WOX } \\
\text { family) }\end{array}$ & $\begin{array}{l}\text { Medicago } \\
\text { truncatula }\end{array}$ & LOF & decreased & & $\begin{array}{l}\text { defective vascular } \\
\text { patterning }\end{array}$ & [136] \\
\hline NsLAM1 & $\begin{array}{l}\text { WOX1 } \\
\text { (WUS/WOX } \\
\text { family) }\end{array}$ & $\begin{array}{l}\text { Nicotiana } \\
\text { sylvestris }\end{array}$ & LOF & decreased & & & [136] \\
\hline MtSTF & $\begin{array}{l}\text { WOX1 } \\
\text { (WUS/WOX } \\
\text { family) }\end{array}$ & Oryza sativa & GOF & increased & & $\begin{array}{l}\text { higher number of } \\
\text { leaf veins, thicker } \\
\text { stems }\end{array}$ & [133] \\
\hline MtSTF & $\begin{array}{l}\text { WOX1 } \\
\text { (WUS/WOX } \\
\text { family) }\end{array}$ & $\begin{array}{l}\text { Panicum } \\
\text { virgatum }\end{array}$ & GOF & increased & & $\begin{array}{l}\text { higher number of } \\
\text { leaf veins, } \\
\text { enhanced } \\
\text { regeneration, } \\
\text { thicker stems }\end{array}$ & [133] \\
\hline PsELE1 & $P P D$ & Pisum sativum & LOF & increased & increased & $\begin{array}{l}\text { disrupted floral } \\
\text { symmetry }\end{array}$ & [63] \\
\hline PsBIO & $\begin{array}{l}\text { KIX8/KIX9 } \\
\text { subfamily }\end{array}$ & Pisum sativum & LOF & increased & increased & $\begin{array}{l}\text { disrupted floral } \\
\text { symmetry }\end{array}$ & [63] \\
\hline PsLATH & $\begin{array}{l}\text { WOX1 } \\
\text { (WUS/WOX } \\
\text { family) }\end{array}$ & Pisum sativum & LOF & decreased & $\begin{array}{l}\text { (in strong } \\
\text { alleles) small } \\
\text { seed pods } \\
\text { without seeds }\end{array}$ & & {$[63,132]$} \\
\hline PtBL & SAP & $\begin{array}{l}\text { Populus } \\
\text { tremula } \times \text { P. } \\
\text { alba }\end{array}$ & GOF & increased & & $\begin{array}{l}\text { more cells per } \\
\text { leaf, increased } \\
\text { adventitious } \\
\text { rooting, reduced } \\
\text { stem diameter and } \\
\text { xylem formation }\end{array}$ & [68] \\
\hline PtBL & SAP & $\begin{array}{l}\text { Populus } \\
\text { tremula } \times \text { P. } \\
\text { alba }\end{array}$ & LOF & decreased & & $\begin{array}{l}\text { decreased leaf cell } \\
\text { number }\end{array}$ & [68] \\
\hline
\end{tabular}




\begin{tabular}{|c|c|c|c|c|c|c|c|}
\hline $\begin{array}{l}\text { Gene } \\
\text { name }\end{array}$ & $\begin{array}{l}\text { Arabidopsis } \\
\text { thaliana } \\
\text { orthologue }\end{array}$ & Organism & Type & $\begin{array}{l}\text { Shoot/leaf } \\
\text { size } \\
\text { phenotype }\end{array}$ & $\begin{array}{l}\text { Seed/fruit } \\
\text { phenotype }\end{array}$ & $\begin{array}{l}\text { Additional } \\
\text { phenotypes }\end{array}$ & Refs. \\
\hline SIKIX8 & KIX8 & $\begin{array}{l}\text { Solanum } \\
\text { lycopersicum }\end{array}$ & LOF & $\begin{array}{l}\text { slightly } \\
\text { increased }\end{array}$ & & & [69] \\
\hline SIKIX9 & KIX9 & $\begin{array}{l}\text { Solanum } \\
\text { lycopersicum }\end{array}$ & LOF & $\begin{array}{l}\text { no } \\
\text { difference }\end{array}$ & & & [69] \\
\hline $\begin{array}{l}\text { SIKIX8 - } \\
\text { SIKIX9 }\end{array}$ & KIX8/KIX9 & $\begin{array}{l}\text { Solanum } \\
\text { lycopersicum }\end{array}$ & LOF & increased & no difference & $\begin{array}{l}\text { delayed flowering, } \\
\text { increased fruit and } \\
\text { pericarp size }\end{array}$ & [69] \\
\hline $\begin{array}{l}\text { VMPPD } \\
\text { (MOG) }\end{array}$ & $P P D$ & Vigna mungo & LOF & increased & increased & faster growth & {$[62]$} \\
\hline
\end{tabular}

aAll comparisons are made to the corresponding wild type plants. GOF: Gain-of-function, LOF: Loss-of-function. 